\title{
The Framework for 0-D Atmospheric Modeling (F0AM) v3.1
}

\author{
Glenn M. Wolfe ${ }^{1,2}$, Margaret R. Marvin ${ }^{3}$, Sandra J. Roberts ${ }^{3}$, Katherine R. Travis ${ }^{4}$, and Jin Liao ${ }^{2,5}$ \\ ${ }^{1}$ Joint Center for Earth Systems Technology, University of Maryland Baltimore County, Baltimore, MD, USA \\ ${ }^{2}$ Atmospheric Chemistry and Dynamics Laboratory, NASA Goddard Space Flight Center, Greenbelt, MD, USA \\ ${ }^{3}$ Department of Chemistry and Biochemistry, University of Maryland, College Park, MD, USA \\ ${ }^{4}$ Department of Earth and Planetary Sciences, Harvard University, Cambridge, MA, USA \\ ${ }^{5}$ Universities Space Research Association, Columbia, MD, USA
}

Correspondence to: Glenn M. Wolfe (glenn.m.wolfe@ nasa.gov)

Received: 5 July 2016 - Published in Geosci. Model Dev. Discuss.: 8 July 2016

Revised: 3 September 2016 - Accepted: 7 September 2016 - Published: 20 September 2016

\begin{abstract}
The Framework for 0-D Atmospheric Modeling (F0AM) is a flexible and user-friendly MATLAB-based platform for simulation of atmospheric chemistry systems. The F0AM interface incorporates front-end configuration of observational constraints and model setups, making it readily adaptable to simulation of photochemical chambers, Lagrangian plumes, and steady-state or time-evolving solar cycles. Six different chemical mechanisms and three options for calculation of photolysis frequencies are currently available. Example simulations are presented to illustrate model capabilities and, more generally, highlight some of the advantages and challenges of 0 -D box modeling.
\end{abstract}

\section{Introduction}

The zero-dimensional (0-D) box model is a fundamental tool of atmospheric chemistry. Myriad chemical and physical processes control atmospheric composition, and 0-D models can harness this complexity to quantify production and loss of reactive species within a chemical system. Box models are routinely used for chemical mechanism inter-comparisons (Archibald et al., 2010; Coates and Butler, 2015; Emmerson and Evans, 2009; Knote et al., 2015), evaluation of field observations (Li et al., 2014; Olson et al., 2006; Stone et al., 2011; Wolfe et al., 2014), and analysis of laboratory chamber experiments (Fuchs et al., 2013; Paulot et al., 2009a).

The power of the 0 -D box model stems partly from its simplicity, but this also imparts inherent limitations. Such models do not explicitly simulate horizontal and vertical transport processes; thus, boundary conditions can strongly in- fluence concentrations of intermediate- to long-lived species like ozone. Steady-state conditions are often assumed when constraining with or comparing to field observations, but this assumption is invalid in some situations (e.g., near large or variable emission sources), and the history of an air mass is not always known. Chemical rate constants and observational constraints also carry significant uncertainties, and the best way to propagate this uncertainty through to model results is not always clear. Thus, one should not necessarily expect a 0-D box model to get "the right answer" except in cases where the model setup is a fair representation of the true atmosphere. Rather, a box model is a platform for gaining conceptual understanding and testing hypotheses through targeted sensitivity simulations and comparison with observations.

There is a need for user-friendly model tools within both the experimental and modeling communities. Several models are currently freely available, including the Dynamically Simple Model for Atmospheric Chemical Complexity (DSMACC) (Emmerson and Evans, 2009), Chemistry As A Box Model Application (CAABA) (R. Sander et al., 2011, 2005), and Box Model Extensions to KPP (BOXMOX) (Knote et al., 2015). These models are written in FORTRAN, which is a preferred language for atmospheric computation but is not the most accessible for novice programmers. Many research groups also develop their own models for specific problems, but this can be a time-consuming and error-fraught effort.

The Framework for 0-D Atmospheric Modeling (F0AM) is a versatile and open platform for simulating atmospheric chemical systems. FOAM is different from other community box models in several respects. First, it is written in a 
high-level programming language. Second, it is easily adaptable to laboratory, Lagrangian, and steady-state applications. Third, it incorporates a suite of common explicit and condensed chemical mechanisms used in the air quality and atmospheric chemistry communities. Here we provide a general description of FOAM architecture, demonstrate several common applications, and suggest potential future improvements. Through this discussion, we also hope to elevate community awareness of the advantages and challenges of the 0-D box modeling approach.

\section{Model description}

Earlier versions of the FOAM architecture evolved from the 1-D Chemistry of Atmosphere-Forest Exchange (CAFE) model, which was designed to resolve physical and chemical processes within a forest canopy (Wolfe and Thornton, 2011; Wolfe et al., 2011a, b). In its previous incarnation, the 0-D model was referred to as the University of Washington Chemical Model (UWCM) and applied to a variety of research problems, including investigation of lab chamber experiments (Kaiser et al., 2014; Wolfe et al., 2012), radical production and volatile organic compound (VOC) oxidation in biogenic environments (Kaiser et al., 2016, 2015; S. Kim et al., 2015, 2013; Wolfe et al., 2014, 2015, 2016), biomass burning plumes (Busilacchio et al., 2016; Müller et al., 2016), and chlorine chemistry (Riedel et al., 2014). Anderson et al. (2016) found excellent agreement between UWCM and DSMACC when modeling ozone production in the tropical western Pacific, adding some confidence to our approach. Several major changes distinguish F0AM from UWCM. While UWCM was built around the Master Chemical Mechanism (MCM), F0AM facilitates use of nearly any chemical mechanism, and a library of common mechanisms is included (Sect. 2.3). Implementing these mechanisms required significant modifications to the photolysis parameterizations, and more options for photolysis are now available (Sect. 2.2). Other new features in F0AM include an option to constrain total $\mathrm{NO}_{x}$ (Sect. 2.1) and improved visualization tools.

The design of F0AM stems from two principles: accessibility and flexibility. Accessibility refers to the ease with which any user can run the model. F0AM is written entirely in MATLAB (developed by MathWorks). MATLAB is a higher-level language than FORTRAN and can be less computationally efficient; however, it is easier to learn for researchers with little programming experience and is used extensively by the experimental community. Though MATLAB itself is not free, F0AM is provided free to the community under the GNU general public license, does not rely on MATLAB toolbox extensions, and is open source to the extent possible. The Supplement includes a detailed user manual and several example setups.
Flexibility refers to the ease with which a user can adapt the model setup to a particular research problem. Front-end options enable various features and simplify switching between parameterizations and mechanisms. All inputs and options are specified in a single script. Example setup scripts cover a range of typical modeling scenarios and can act as a starting point for new scenarios or datasets. For common applications, users should not have to modify source code.

A general overview of model inputs, outputs, and parameterizations is given below. Here, a model "run" refers to a single model call, while a model "step" refers to model execution for a single set of initial meteorological and chemical conditions. There can be multiple steps within a run.

\subsection{Observational constraints}

Required meteorological inputs include pressure, temperature, and water vapor content. Several options are available to drive the various photolysis schemes (described further below), including direct input of observed photolysis frequencies ( $J$ values), solar zenith angles, or an actinic flux spectrum. Concentrations for each chemical species within a given mechanism can be initialized and/or constrained to observations or user-specified values; the default initial concentration is 0 . The way chemical constraints are handled depends on the specific scenario. Any constrained species can be held constant throughout a model step, which may be desirable when simulating diurnal cycles using discrete observations (Sects. 3.3 and 3.4). Alternatively, concentrations can be initialized at the beginning of a step and allowed to evolve over time, which may be more appropriate when modeling laboratory experiments or Lagrangian plumes (Sects. 3.1 and 3.2).

A special option is available to force total $\mathrm{NO}_{x}$ $\left(=\mathrm{NO}+\mathrm{NO}_{2}\right)$ to input values at the beginning of each step. This provides a means of replenishing $\mathrm{NO}_{x}$ without perturbing the modeled $\mathrm{NO} / \mathrm{NO}_{2}$ ratio, which may be desirable, e.g., for diurnal cycles of radical chemistry. Figure $1 \mathrm{com}-$ pares predicted and observed $\mathrm{NO}_{x}$ mixing ratios for a diurnal cycle simulation using this option (see Sect. 3.2 for details). For this particular example, daytime NO is slightly overpredicted, while $\mathrm{NO}_{2}$ is underpredicted, which could be related to the model $\mathrm{NO}_{2}$ photolysis frequency (which is not measurement-constrained). Total model $\mathrm{NO}_{x}$ is lower than observations by $2 \pm 4 \%$ on average. When using this option, it is preferable to keep the model step interval significantly smaller than the $\mathrm{NO}_{x}$ lifetime to minimize $\mathrm{NO}_{x}$ loss over the course of a step. In this example the step interval is $15 \mathrm{~min}$ and the mid-day $\mathrm{NO}_{x}$ lifetime is on the order of hours.

\subsection{Photolysis}

Photolysis frequencies control radical production and the lifetimes of numerous compounds. Accurate simulation of $J$ values is challenging due to the variety of factors that influ- 


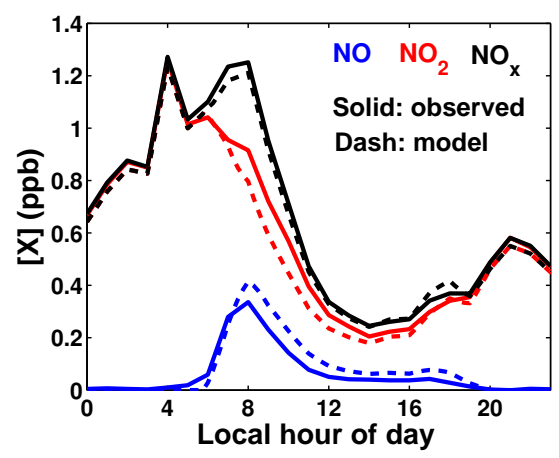

Figure 1. Comparison of simulated (dashed) and observed (solid) mixing ratios of $\mathrm{NO}$ (blue), $\mathrm{NO}_{2}$ (red), and $\mathrm{NO}_{x}$ (black) for the diurnal cycle setup described in Sect. 3.2. This simulation uses the "fix $\mathrm{NO}_{x}$ " option, which resets total $\mathrm{NO}_{x}$ to the observed value at the start of every step (15 min, in this case) while maintaining the model-calculated $\mathrm{NO} / \mathrm{NO}_{2}$ ratio.

ence the radiation field, many of which are often unknown or require some effort to determine (e.g., surface albedo, overhead ozone column, cloud and aerosol extinction or enhancement). F0AM provides three options for calculating $J$ values: bottom-up, MCM, and hybrid.

In the "bottom-up" method, $J$ values are calculated by integrating the product of a user-specified actinic flux spectrum with literature-derived cross sections and quantum yields. Cross sections and quantum yields are taken from the latest IUPAC (Atkinson et al., 2004, 2006) and JPL (S. P. Sander et al., 2011) recommendations when available, and all sources are documented in a single spreadsheet. Spectra, cross sections and quantum yields are convolved using a trapezoidal integration algorithm identical to that employed in NCAR's Tropospheric Ultraviolet and Visible radiation model (TUVv5.2, available at https://www2.acom.ucar.edu/modeling/ tropospheric-ultraviolet-and-visible-tuv-radiation-model).

This option is most useful when simulating photochemical chamber experiments with non-solar light sources.

The Master Chemical Mechanism (MCM) provides a trigonometric parameterization based on solar zenith angle (SZA).

$J=I \cos (\mathrm{SZA})^{m} \exp (-n \sec (\mathrm{SZA}))$

Here, $I, m$, and $n$ are constants unique to each photolysis reaction, derived from least-squares fits to $J$ values computed with fixed solar spectra and literature cross-section and quantum yields. As discussed in Jenkin et al. (1997) and Saunders et al. (2003), solar spectra underlying this parameterization were calculated from a two-stream radiative transfer model for clear sky conditions on 1 July at a latitude of $45^{\circ} \mathrm{N}$ and an altitude of $0.5 \mathrm{~km}$. Cross sections and quantum yields generally follow IUPAC recommendations as documented on the MCM website (http://mcm.leeds.ac.uk/MCM/). When using this option with a chemical mechanism other than the MCM, photolysis frequencies for reactions not included in the MCM are calculated using the "hybrid" method (below) with a fixed altitude of $0.5 \mathrm{~km}$, overhead ozone column of $350 \mathrm{DU}$ and surface albedo of 0.01 . The ozone column and albedo are chosen to optimize agreement between the MCM and hybrid values of $J\left(\mathrm{NO}_{2}\right)$ and $J\left(\mathrm{O}\left({ }^{1} \mathrm{D}\right)\right)$.

The "hybrid" method is essentially an extension of the bottom-up method, combining cross sections and quantum yields from the latter with solar spectra derived from TUVv5.2. A total of 20064 solar spectra were calculated offline over a range of SZA (minimum/increment/maximum of $\left.0 / 5 / 90^{\circ}\right)$, altitude $(0 / 1 / 15 \mathrm{~km})$, overhead ozone column $(100 / 50 / 600 \mathrm{DU})$, and albedo (0/0.2/1) values. $J$ values calculated for all solar spectra are organized into a set of lookup tables. At the start of a model run, input SZA, altitude, ozone column, and albedo are used for linear interpolation across these tables. This method extends the number of available photolysis frequencies well beyond those included in the MCM parameterization while avoiding the computational expense of running the full TUV model inline. Also, the hybrid method is fully traceable: cross sections and quantum yields are documented in a single file, and both TUV-derived actinic fluxes and the code for calculating $J$ value lookup tables are available upon request.

Figure 2 compares photolysis frequencies calculated with the MCM parameterization and the F0AM hybrid method for a single set of inputs $\left(\mathrm{SZA}=0^{\circ}\right.$, altitude $=0.5 \mathrm{~km}$, albedo $=0.01, \mathrm{O}_{3}$ column $\left.=350 \mathrm{DU}\right)$. The overhead $\mathrm{O}_{3}$ column and albedo for this comparison are chosen to optimize average agreement between the hybrid and MCM values, since the exact solar spectra underlying the MCM parameterization are not available. The two methods agree to within $\pm 20 \%$ for inorganics, organic nitrates and some VOCs. Agreement is more variable for larger VOCs, in part due to varying quantum yields; for example, MCM uses different branching ratios for the glyoxal photolysis channels than those recommended by JPL or IUPAC. Figure 2 also compares hybrid values with those output directly by TUVv5.2, which includes its own photolysis algorithm. Photolysis frequencies for these two methods generally agree to within $\pm 20 \%$, as expected since both utilize identical solar spectra and generally comparable cross sections and quantum yields. Differences for $\mathrm{N}_{2} \mathrm{O}_{5}, \mathrm{CH}_{3} \mathrm{CHO}$, and MEK photolysis stem from the choice of quantum yields. Differences for $\mathrm{C}_{2} \mathrm{H}_{5} \mathrm{CHO}$ and $\mathrm{CH}_{3} \mathrm{COCH}_{3}$ photolysis are due to known errors in TUVv5.2 that will be resolved in the next release (S. Madronich, personal communication, 2016). Based on the above comparison, we recommend the hybrid method over the MCM parameterization for most "real atmosphere" simulations.

Any $J$ value can be constrained to observations via direct input. It is also possible to specify a scaling factor for all parameterized $J$ values. Typically this scaling is taken as the ratio of an observed photolysis frequency to its modelcalculated value. Scaling to observed values is encouraged 

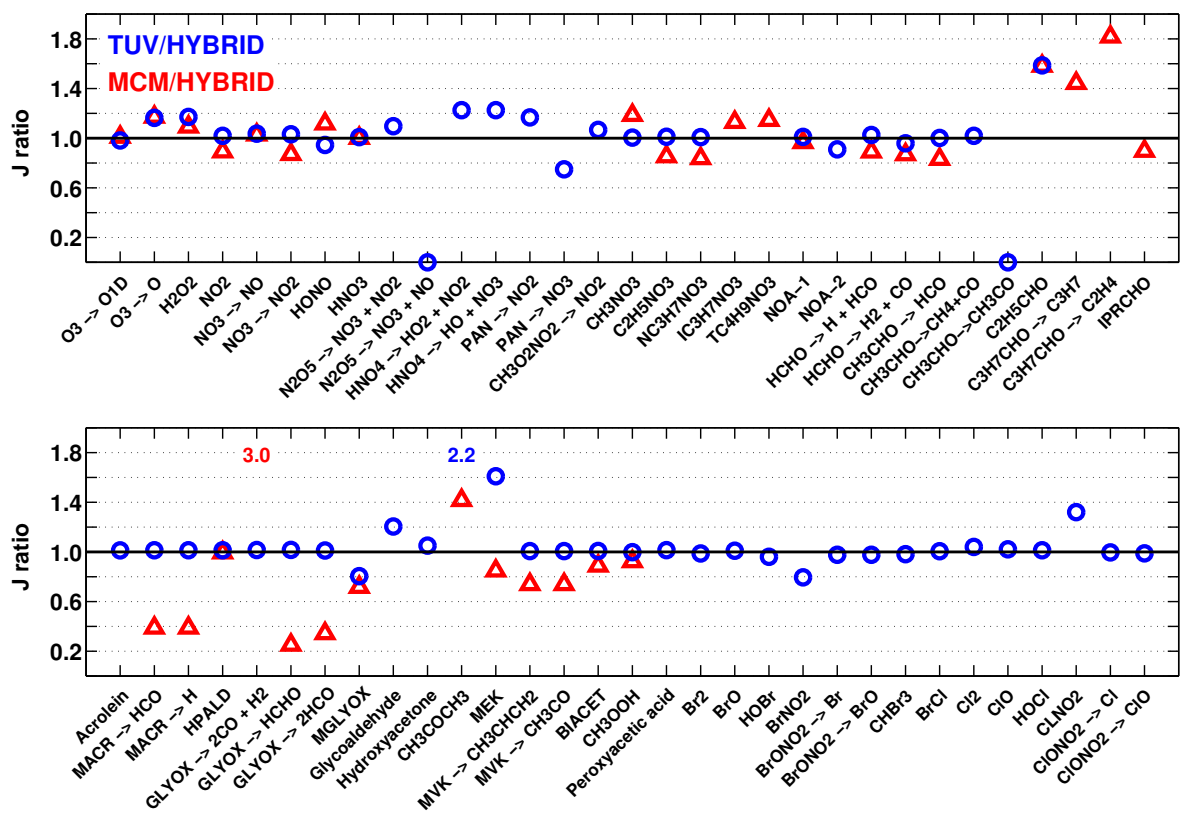

Figure 2. Ratio of photolysis frequencies calculated from the MCMv3.3.1 SZA parameterization (red triangles) and TUVv5.2 (blue circles) against the F0AM hybrid method. Ratios are taken for $J$ values calculated with a single set of inputs $\left(\mathrm{SZA}=0^{\circ}\right.$, altitude $=0.5 \mathrm{~km}$, albedo $=0.01, \mathrm{O}_{3}$ column $=350 \mathrm{DU}$ ). Blue and red numbers denote values falling outside the $y$ axis range. The hybrid scheme includes photolysis frequencies for all listed reactions. Reactions with missing values do not have TUV or MCM analogs.

when working with field observations, as neither the MCM or hybrid methods capture the full extent of atmospheric properties that can influence solar radiation. For example, in the steady-state simulation discussed in Sect. 3.4, removing observation-based constraints on $J\left(\mathrm{NO}_{2}\right)$ and $J\left(\mathrm{O}^{1} \mathrm{D}\right)$ increases average calculated $\mathrm{NO}, \mathrm{OH}$, and $\mathrm{HCHO}$ mixing ratios by 34,40 , and $11 \%$, respectively.

\subsection{Chemistry}

Table 1 lists the gas-phase chemical mechanisms currently available with FOAM. The MCM is a prevalent explicit mechanism, and version 3.3.1 (Jenkin et al., 2015) contains numerous updates to reflect recent laboratory and theoretical advances. MCMv3.2 (Saunders et al., 2003) is included for comparison purposes. Several MCM extensions are also available, including simplified monoterpene and sesquiterpene oxidation (Wolfe and Thornton, 2011), chlorine-VOC reactions (Riedel et al., 2014), and a subset of bromine and chlorine reactions from MECCA (R. Sander et al., 2011). The Carbon Bond mechanisms, CB05 (Yarwood et al., 2005) and CB6r2 (Hildebrandt Ruiz and Yarwood, 2013), and the Regional Atmospheric Chemistry Mechanism version 2 (RACM2) (Goliff et al., 2013) are condensed mechanisms commonly used in regional air quality applications. The version of the GEOS-Chem mechanism included with FOAM is based on GEOS-Chem v9-02 (Mao et al., 2013) with updates to isoprene chemistry as described in several recent publications (Fisher et al., 2016; P. S. Kim et al., 2015; Marais et al.,
2016; Travis et al., 2016). Toggling between various mechanisms is straightforward through the setup script. None of the above mechanisms include heterogeneous or aerosol-phase processes.

Chemical rate equations are integrated with MATLAB's ode15s solver, which is designed specifically for stiff systems. A utility is available for converting mechanisms from the FACSIMILE (MCPA Software) format into the FOAM input format, and a similar utility for converting KPPformatted mechanisms (Damian et al., 2002) may be included in a future release. We hope that the community will continue to add to the F0AM mechanism library and that this model can serve as a platform for inter-comparing and evaluating updates to these mechanisms.

\subsection{Dilution}

A major shortcoming of the 0-D box modeling approach is the lack of explicit representation of transport processes (entrainment, dilution, etc.), which has several practical consequences. First, primary emissions like $\mathrm{NO}_{x}$ and hydrocarbons must be constrained or otherwise re-supplied to compensate for chemical loss. Emissions can also be parameterized explicitly but require knowledge of the boundary layer depth and assumed instantaneous mixing. Second, a generic "physical loss" lifetime of 6-48 h is often assigned to all species to mitigate build-up of long-lived oxidation products over multiple days of integration. Model users must be aware of the limitations imposed by these choices. For exam- 
Table 1. Chemical mechanisms in F0AM v3.1.

\begin{tabular}{lrrl}
\hline Mechanism & No. of species & No. of reactions & Reference \\
\hline MCM v3.3.1 & $\begin{array}{r}610^{\mathrm{a}} \\
5832^{\mathrm{b}}\end{array}$ & $\begin{array}{r}1974^{\mathrm{a}} \\
17224^{\mathrm{b}}\end{array}$ & Jenkin et al. (2015) \\
\hline MCM v3.2 & $\begin{array}{r}455^{\mathrm{a}} \\
5734^{\mathrm{b}}\end{array}$ & $\begin{array}{r}1476^{\mathrm{a}} \\
16940^{\mathrm{b}}\end{array}$ & Saunders et al. (2003) \\
\hline CB05 & 53 & 156 & Yarwood et al. (2005) \\
\hline CB6r2 & 77 & 216 & Hildebrandt Ruiz and Yarwood (2013) \\
\hline RACM2 & 124 & 363 & Goliff et al. (2013) \\
\hline GEOS-Chem & 171 & 505 & $\begin{array}{l}\text { Mao et al. (2013); Marais et al. (2016); } \\
\text { Fisher et al. (2016); Travis et al. (2016); }\end{array}$ \\
& & & P. S. Kim et al. (2015) \\
\hline
\end{tabular}

${ }^{\mathrm{a}}$ Isoprene, methane, and inorganic reactions only. ${ }^{\mathrm{b}}$ Full mechanism.

ple, constraining $\mathrm{NO}_{2}$ is not appropriate when investigating ozone production, and the choice of physical loss lifetime can affect simulated $\mathrm{OH}$ reactivity (Edwards et al., 2013; Kaiser et al., 2016).

FOAM adopts a simple parameterization for first-order ventilation:

$\frac{\mathrm{d}[X]}{\mathrm{d} t}=-k_{\mathrm{dil}}\left([X]-[X]_{\mathrm{b}}\right)$.

Here, $[X]$ is the chemical concentration, $[X]_{\mathrm{b}}$ is a fixed "background" concentration, and $k_{\text {dil }}$ is a first-order dilution rate constant. Expansion of Eq. (2) shows that this parameterization is effectively the combination of a zeroth-order source $\left(k_{\mathrm{dil}}[X]_{\mathrm{b}}\right)$ and a first-order sink $\left(-k_{\mathrm{dil}}[X]\right)$. The choice of $k_{\mathrm{dil}}$ and $[X]_{\mathrm{b}}$ depends on the particular problem. The dilution rate constant can be set to a constant value or parameterized using additional information, such as the decrease in conserved tracers in evolving plumes (Dillon et al., 2002; Müller et al., 2016), wind speed (Bryan et al., 2012), or boundary layer growth rate (Kaiser et al., 2016). Background concentrations are typically set to up-wind, out-of-plume, or free tropospheric values, depending on the system and available information. Setting $[X]_{\mathrm{b}}$ to zero yields a simple first-order sink, analogous to the physical loss lifetime discussed above. Regardless of the application, it is important to justify the choice of $k_{\mathrm{dil}}$ and $[X]_{\mathrm{b}}$ and/or perform sensitivity simulations to characterize how uncertainties in physical processes impact model interpretation.

\subsection{Execution options}

Much of the flexibility of F0AM stems from up-front control of how integration proceeds across a single step and between steps. For example, the end points of one step can be used to initialize the next step, or each step can be treated as independent. The former option is appropriate for simulating the time evolution of field observations (which may have time- varying input constraints), while the latter is useful for modeling multiple chamber experiments or performing a sensitivity study (e.g., the effect of varying levels of $\mathrm{NO}_{x}$ on isoprene oxidation). A "solar cycle" option is also available to make photolysis frequencies evolve "in real time" over the course of a model step, which is a standard procedure when modeling aircraft observations (Olson et al., 2006). In this case, the user must also specify location and time. It is left to the user to determine the appropriate total integration time - no convergence criteria are incorporated into model execution.

\subsection{Output and analysis}

Model output is collected in a single hierarchical structure and includes calculated chemical concentrations and reaction rates, as well as inputs. Outputs can include all intermediate concentrations and rates along each step or values at the end of the step only (specified during setup). Tools are also provided for manipulating and plotting output; some example plots are shown below. One tool of special note is a function to identify MCM species with specific chemical functionalities (carbonyls, nitrates, etc.) using simplified molecular input line entry system (SMILES) strings (Weininger, 1988). This tool is useful for examining groups of compounds (e.g., Fig. 4) and has been used previously to develop a rough deposition parameterization for many MCM species (Kaiser et al., 2016).

\section{Example applications}

Here we describe several common applications and demonstrate typical methods for analysis of model output. Model setup files and input data for all examples described here are included with the FOAM distribution. 


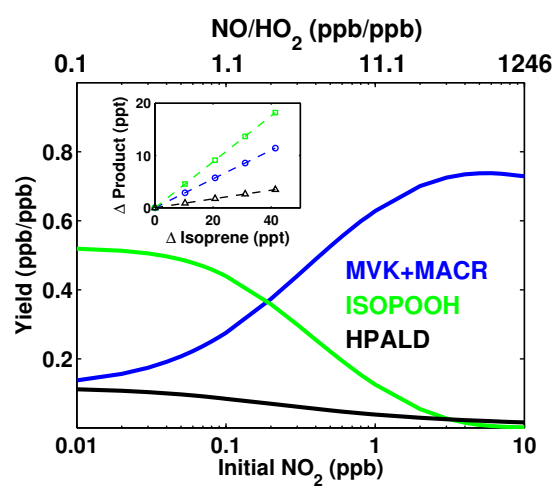

Figure 3. Theoretical yields of first-generation isoprene oxidation products for a series of isoprene oxidation experiments with varying levels of $\mathrm{NO}_{x}$ (Sect. 3.1). Yields are calculated as the slope of product formed vs. isoprene lost over minutes $10-15$ of oxidation (example shown in inset). The upper axis shows average $\mathrm{NO} / \mathrm{HO}_{2}$ ratios over the same period.

\subsection{Photochemical chamber}

Photochemical chambers are a standard tool for isolating and characterizing chemical processes. 0-D models are useful for both planning experiments and interpreting data (e.g., by testing proposed mechanism modifications). Here, we use F0AM with MCMv3.3.1 to predict $\mathrm{NO}_{x}$-dependent yields of several isoprene oxidation products. For these simulations, model meteorology is set to nominal values $(298 \mathrm{~K}$, 1000 mbar, $10 \% \mathrm{RH}) . J$ values are calculated using the "bottom-up" method with a light spectrum corresponding to UV bulbs with output centered at $350 \mathrm{~nm}$ (Crounse et al., 2011). The model is initialized with $10 \mathrm{ppb}$ of isoprene, $200 \mathrm{ppb}$ of hydrogen peroxide (a common $\mathrm{OH}$ source), and $\mathrm{NO}_{2}$ mixing ratios ranging from $10 \mathrm{ppt}$ to $10 \mathrm{ppb}$. The model is integrated to $1 \mathrm{~h}$ for each initial $\mathrm{NO}_{2}$ concentration, and yields are calculated as the slope of product gained against isoprene lost over minutes 10-15 (see inset in Fig. 3). We do not consider wall losses in this simple example, but such processes are typically represented with additional first-order loss reactions (Wolfe et al., 2012).

Figure 3 shows the yields of three first-generation products that track the fate of isoprene hydroxyperoxy radicals $\left(\mathrm{ISOPO}_{2}\right)$ : methyl vinyl ketone (MVK) and methacrolein (MACR) from the NO channel, isoprene hydroxyhydroperoxides (ISOPOOH) from the $\mathrm{HO}_{2}$ channel, and hydroperoxyaldehydes (HPALD) from unimolecular isomerization. The chemistry shifts from $\mathrm{HO}_{2}$ - to NO-dominated at $0.2 \mathrm{ppb}$ of initial $\mathrm{NO}_{2}$. Such plots can help define optimal experiment conditions and strengthen intuition regarding expected relationships in both the laboratory and the real atmosphere.

\subsection{Lagrangian plume evolution}

The time evolution of a plume - from a wildfire, urban core, power plant, or other strong emitter - offers a natural experiment for testing chemical understanding. As an example, we simulate a young biomass burning plume sampled from an aircraft during NASA's DISCOVER-AQ mission (Deriving Information on Surface Conditions from Column and Vertically Resolved Observations Relevant to Air Quality, data available at DOI 10.5067/Aircraft/DISCOVER-AQ/AerosolTraceGas). Plume sampling occurred longitudinally from the source to $\sim 13.5 \mathrm{~km}$ downwind, corresponding to a processing time of $\sim 1 \mathrm{~h}$. Model setup is identical to that described in Müller et al. (2016). Briefly, gas concentrations are initialized with mixing ratios observed over the first $1 \mathrm{~km}$ and include $\mathrm{O}_{3}, \mathrm{CO}, \mathrm{CH}_{4}, \mathrm{NO}, \mathrm{NO}_{2}, \mathrm{HONO}$, and a suite of 17 reactive VOCs. All gas concentrations are allowed to evolve freely in time. Meteorological conditions are updated every $250 \mathrm{~s}$ (roughly every $1 \mathrm{~km}$ ). The dilution constant is calculated using the observed decay of $\mathrm{CO}$; the dilution lifetime $\left(1 / k_{\text {dil }}\right)$ increases from 6 min to 106 min over the simulation period. Background concentrations are taken from measurements outside the plume. MCMv3.3.1 chemistry is employed using MCM's default photolysis scheme, with additional reactions for initial oxidation of furfural and furan.

Figure 4 illustrates the simulated progression of total oxidized nitrogen $\left(\mathrm{NO}_{y}\right) . \mathrm{NO}_{x}$ decreases by over a factor of 2 over the course of an hour, but this is mostly balanced by formation of peroxy nitrates (mainly peroxyacetyl nitrate, PAN) and nitric acid. As presented in Müller et al. (2016), the model quantitatively replicates the observed conversion of $\mathrm{NO}_{x}$ to PAN, as well as the formation of $\sim 60 \mathrm{ppb}$ of ozone. The excellent model-measurement agreement for this case suggests that more advanced frameworks that account for Gaussian dispersion (Alvarado and Prinn, 2009) may not always be necessary, but this likely depends on the nature of each case study and available constraints. On the other hand, the model does not capture the increase in some oxidized VOCs, such as formaldehyde, likely indicating some missing VOC precursors. In conjunction with a detailed dataset, a box model can help to characterize the nature of such "missing" reactants and quantify the impact of these compounds on downwind chemistry.

\subsection{Boundary layer diurnal cycle}

Ground-based field intensives can provide detailed data sets for driving model simulations. Here we use a subset of observations from the 2013 Southeast Oxidants and Aerosol Study (SOAS, data available at http://www.eol.ucar.edu/ field_projects/sas). Observations from the Centreville, Alabama, site are averaged over the entire campaign to a diurnal cycle in $1 \mathrm{~h}$ intervals. There is substantial day-to-day variability in this dataset, and this coarse averaging procedure is for illustrative purposes only. Chemical constraints include 


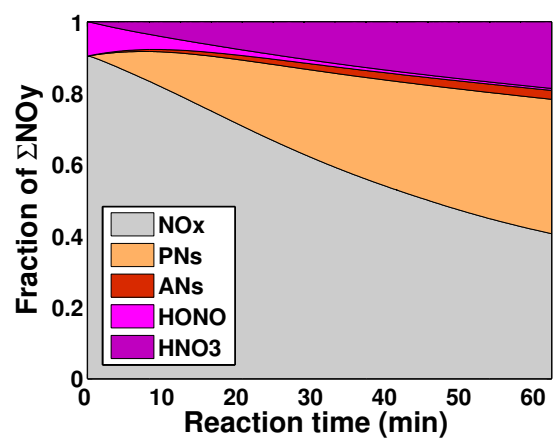

Figure 4. Simulated evolution of total oxidized nitrogen in a nascent biomass burning plume as described in Sect. 3.2. "PNs" represents all peroxy nitrates, and "ANs" represents all alkyl nitrates. The PNs and ANs groups were generated using an algorithm that scans MCM SMILES strings (see Sect. 2.6).

$\mathrm{NO}_{x}, \mathrm{OH}, \mathrm{CO}, \mathrm{PAN}$, and a suite of $\sim 35$ VOCs. Total $\mathrm{NO}_{x}$ is semi-constrained using the "fixed $\mathrm{NO}_{x}$ " option (Fig. 1), and to facilitate this we interpolate the hourly averaged data to a 15 min time base. Ozone is initialized for the first step only. We use MCMv3.3.1 chemistry and the hybrid $J$ value parameterization with a fixed $\mathrm{O}_{3}$ column of $320 \mathrm{DU}$ and albedo of 0.05 , without further scaling (no radiation measurements are available). A physical loss lifetime of $24 \mathrm{~h}$ (using the dilution parameterization) is applied to all species. The model run extends over 4 days, using the same constraints for each day.

Figure 5a shows the evolution of ozone over the 4-day simulation period. Ozone is in near-steady state by the end of the fourth day; concentrations increase by less than $2 \%$ between days 3 and 4 . Ozone growth is rapid in the morning but slows around noon, concomitant with reduced $\mathrm{NO}_{x}$ (Fig. 1). The dominant fate of organic peroxy radicals also shifts from reaction with $\mathrm{NO}$ to reaction with $\mathrm{HO}_{2}$ at this time (Fig. 5b), which likely also contributes to reduced ozone production (less radical cycling) and may impact production of aerosol precursors, such as epoxides (Paulot et al., 2009b). Through sensitivity simulations that probe the timing of such changes, box modeling facilitates rapid-fire testing of multiple hypotheses and full leveraging of comprehensive datasets.

Despite good model-measurement agreement for peak ozone mixing ratios in the afternoon, significant discrepancies occur at other times. Between hours 07:00 and 12:00 local solar time, observed ozone increases by $23 \mathrm{ppb}$, while modeled values only increase by $15 \mathrm{ppb}$. This is likely due to a lack of residual layer entrainment in the model, which can be a significant ozone source in the morning (Su et al., 2016). The model also underpredicts the evening ozone decay rate by a factor of 2 , potentially implying inadequate treatment of deposition (dilution is the only physical loss in our setup). These issues highlight some of the challenges of simulating near-surface composition in a complex environment with a

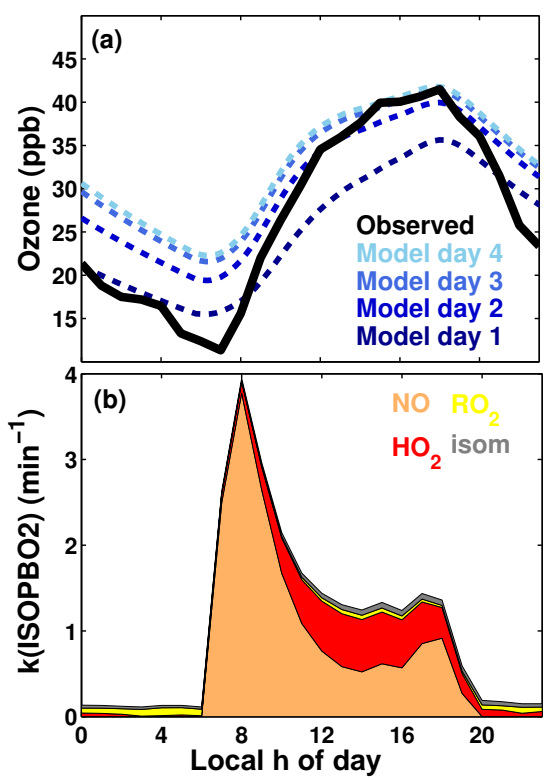

Figure 5. (a) Progression of a simulated diurnal ozone profile (dashed lines) over 4 days of a constrained boundary layer diurnal cycle simulation (Sect. 3.3). Observed ozone is also shown (solid black line). (b) Reactivity of a representative first-generation isoprene hydroxyperoxy radical against reaction with NO (orange), $\mathrm{HO}_{2}$ (red), other $\mathrm{RO}_{2}$ (yellow) and $1.5 \mathrm{H}$-shift isomerization. Rates are taken from the final simulation day.

relatively simple model. Additional functionality could be added in the future to better represent physical processes.

\subsection{Mechanism inter-comparison}

Regional and global models employ a variety of chemical mechanisms. Box models can isolate the chemistry contribution to inter-model differences and pinpoint potential shortcomings in condensed mechanisms. Here we show an example comparison between all mechanisms included in F0AM (Table 1). Constraints are taken from airborne observations acquired in the Atlanta area during the 12 June 2013 flight of the Southeast Nexus mission (SENEX, data available at http://esrl.noaa.gov/csd/groups/csd7/measurements/ 2013senex/P3/DataDownload/) (Warneke et al., 2016). Figure $6 \mathrm{a}$ shows time series of altitude, $\mathrm{NO}_{x}$, and isoprene mixing ratios for the representative flight segment, which includes (chronologically) a vertical profile, a boundary layer transect downwind of a power plant plume, and a pass through the Atlanta urban core. Chemical constraints include $1 \mathrm{~min}$ average observations of $\mathrm{CH}_{4}, \mathrm{CO}, \mathrm{O}_{3}, \mathrm{NO}_{2}, \mathrm{PAN}$, methanol, and isoprene. Hybrid $J$ values are corrected by the average ratio of observed-to-calculated $J\left(\mathrm{NO}_{2}\right)$ and $J\left(\mathrm{O}^{1} \mathrm{D}\right)$. For each $1 \mathrm{~min}$ interval, the model is run with a $1 \mathrm{~h}$ time step for 5 days in "solar cycle" mode to achieve steady state.

Figure 6b, c, and d compare modeled $\mathrm{OH}, \mathrm{HO}_{2}$, and $\mathrm{OH}$ reactivity (inverse $\mathrm{OH}$ lifetime) for all mechanisms. $\mathrm{OH}$ con- 


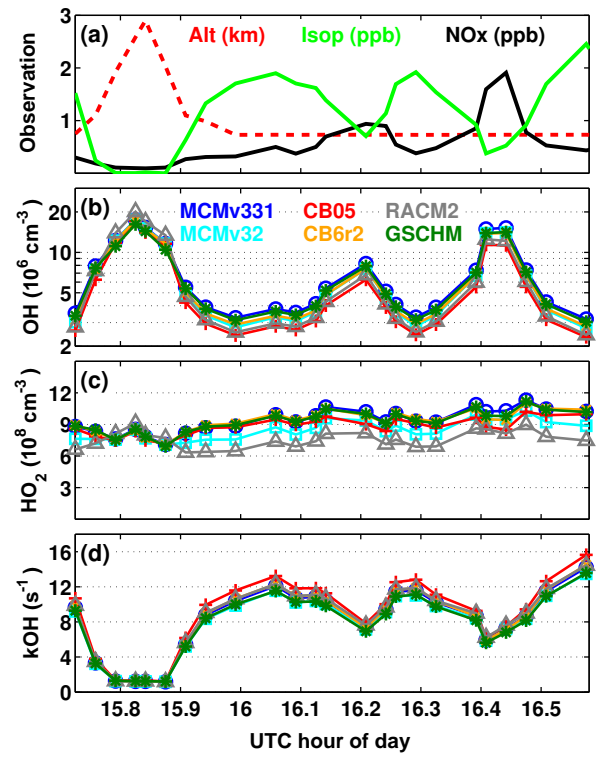

Figure 6. (a) Time series of pressure altitude (red dashed line) and observed mixing ratios of isoprene (green line) and $\mathrm{NO}_{x}$ (black line) for the SENEX Atlanta area flight leg discussed in Sect. 3.4. Observations from this dataset drive steady-state simulations for comparison of modeled $\mathrm{OH}(\mathbf{b}), \mathrm{HO}_{2}$ (c), and $\mathrm{OH}$ reactivity (d) among six chemical mechanisms: MCMv3.3.1 (blue circles), MCMv3.2 (cyan squares), CB05 (red +), CB6r2 (orange $\times$ ), RACM2 (gray triangles), and GEOS-Chem (green asterisks).

centrations agree to within $\pm 30 \%$, and $\mathrm{HO}_{2}$ concentrations and $\mathrm{OH}$ reactivity to within $20 \%$, over the whole period. Even this relatively short simulation is revealing. For example, both the MCM and carbon bond mechanisms exhibit an increase in $\mathrm{OH}$ and $\mathrm{HO}_{2}$ between the old and new mechanism versions. The most obvious discrepancy between the chosen mechanisms is the somewhat low value of $\mathrm{HO}_{2}$ for RACM2. To investigate further, we can compare rates of $\mathrm{HO}_{2}$ production and loss between RACM2 and MCMv3.3.1. $\mathrm{HO}_{2}$ lifetimes of $10-50 \mathrm{~s}$ are nearly identical for both mechanisms; thus, the difference must be related to production. Figure 7 compares $\mathrm{HO}_{2}$ sources for the two mechanisms. The production of $\mathrm{HO}_{2}$ from $\mathrm{OH}$ reactions with $\mathrm{HCHO}$, $\mathrm{CO}$, and other compounds is significantly slower in RACM2. RACM2 OH concentrations, however, fall in the middle of the pack. Furthermore, $\mathrm{HO}_{x}$ agreement is much better in the high-altitude portion, where isoprene is absent. Taken together, these results suggest minor discrepancies in the distribution of isoprene oxidation products in RACM2. The utility of direct rate analysis afforded by box models cannot be overstated, especially for chemical species with multiple sources and sinks. A true mechanism evaluation also requires comparison to measurements where possible. The SENEX dataset lacks $\mathrm{HO}_{x}$ observations, but it does include a wide range of isoprene oxidation products. Work is ongoing to evaluate isoprene chemistry within these mechanisms

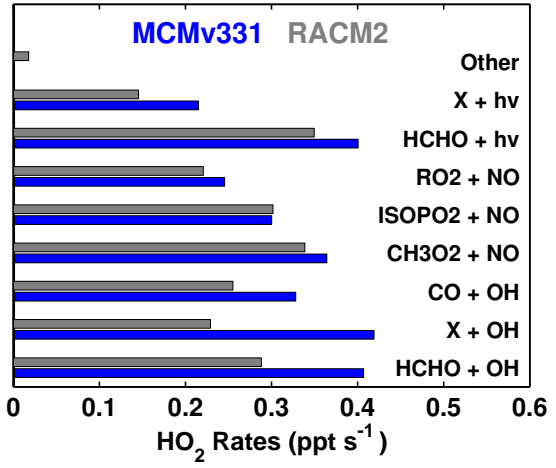

Figure 7. Comparison of $\mathrm{HO}_{2}$ sources for the MCMv331 (blue) and RACM2 (gray) steady-state simulations. Production rates are instantaneous values from the model step at UTC hour 16.2 (see Fig. 6). In the labels, " $\mathrm{X}$ " and "RO2" refer to all $\mathrm{HO}_{2}$-producing species other than those listed explicitly.

using observations of $\mathrm{HCHO}$ and other species from the full SENEX mission (Marvin et al., 2016).

\section{Future functionality}

F0AM is a community tool that will continue to evolve. A range of modifications are envisioned to improve functionality, including

- propagation of uncertainties in constraints and rate constants, e.g., using Monte Carlo methods;

- explicit deposition and emission parameterizations;

- gas-particle partitioning and heterogeneous chemistry;

- a Lagrangian trajectory model interface and

- tagging of oxidation products for source apportionment.

- Development of these capabilities will be driven by the specific requirements of new modeling projects.

\section{Code availability}

F0AM is available for download at https://sites.google.com/ site/wolfegm/models. Version 3.1 is included as a supplement to this publication. Frequent users are also encouraged to join the F0AMusers@googlegroups.com mailing list/forum and to share newly developed code with the community.

The Supplement related to this article is available online at doi:10.5194/gmd-9-3309-2016-supplement. 
Acknowledgements. We are grateful to Kirk Ullmann for providing the TUV model executable and Markus Müller for providing the setup and data for the Lagrangian plume example. Photolysis parameterizations are based on code developed by John Crounse, Fabian Paulot, and Wyatt Merrill. Jen Kaiser provided helpful feedback on the model documentation. Emma D'Ambro provided helpful comments on the manuscript. We are also indebted to the many scientists and crew members of the DISCOVER-AQ, SENEX and SOAS field missions for collecting observations used to constrain the example simulations. Glenn M. Wolfe acknowledges support from the NOAA Climate and Global Change Postdoctoral Fellowship Program and NASA ACCDAM grant NNX14AP48G. Margaret R. Marvin acknowledges support from a NASA Earth Systems Science Fellowship.

Edited by: A. B. Guenther

Reviewed by: K. M. Emmerson and one anonymous referee

\section{References}

Alvarado, M. J. and Prinn, R. G.: Formation of ozone and growth of aerosols in young smoke plumes from biomass burning: 1. Lagrangian parcel studies, J. Geophys. Res.-Atmos., 114, D09306, doi:10.1029/2008jd011144, 2009.

Anderson, D. C., Nicely, J. M., Salawitch, R. J., Canty, T. P., Dickerson, R. R., Hanisco, T. F., Wolfe, G. M., Apel, E. C., Atlas, E., Bannan, T., Bauguitte, S., Blake, N. J., Bresch, J. F., Campos, T. L., Carpenter, L. J., Cohen, M. D., Evans, M., Fernandez, R. P., Kahn, B. H., Kinnison, D. E., Hall, S. R., Harris, N. R., Hornbrook, R. S., Lamarque, J. F., Le Breton, M., Lee, J. D., Percival, C., Pfister, L., Pierce, R. B., Riemer, D. D., Saiz-Lopez, A., Stunder, B. J., Thompson, A. M., Ullmann, K., Vaughan, A., and Weinheimer, A. J.: A pervasive role for biomass burning in tropical high ozone/low water structures, Nat. Commun., 7, 10267, doi:10.1038/ncomms10267, 2016.

Archibald, A. T., Jenkin, M. E., and Shallcross, D. E.: An isoprene mechanism intercomparison, Atmos. Environ., 44, 5356-5364, doi:10.1016/j.atmosenv.2009.09.016, 2010.

Atkinson, R., Baulch, D. L., Cox, R. A., Crowley, J. N., Hampson, R. F., Hynes, R. G., Jenkin, M. E., Rossi, M. J., and Troe, J.: Evaluated kinetic and photochemical data for atmospheric chemistry: Volume $\mathrm{I}-$ gas phase reactions of $\mathrm{O}_{x}, \mathrm{HO}_{x}, \mathrm{NO}_{x}$ and $\mathrm{SO}_{x}$ species, Atmos. Chem. Phys., 4, 1461-1738, doi:10.5194/acp-41461-2004, 2004.

Atkinson, R., Baulch, D. L., Cox, R. A., Crowley, J. N., Hampson, R. F., Hynes, R. G., Jenkin, M. E., Rossi, M. J., Troe, J., and IUPAC Subcommittee: Evaluated kinetic and photochemical data for atmospheric chemistry: Volume II - gas phase reactions of organic species, Atmos. Chem. Phys., 6, 3625-4055, doi:10.5194/acp-6-3625-2006, 2006.

Bryan, A. M., Bertman, S. B., Carroll, M. A., Dusanter, S., Edwards, G. D., Forkel, R., Griffith, S., Guenther, A. B., Hansen, R. F., Helmig, D., Jobson, B. T., Keutsch, F. N., Lefer, B. L., Pressley, S. N., Shepson, P. B., Stevens, P. S., and Steiner, A. L.: Incanopy gas-phase chemistry during CABINEX 2009: sensitivity of a 1-D canopy model to vertical mixing and isoprene chemistry, Atmos. Chem. Phys., 12, 8829-8849, doi:10.5194/acp-12-88292012, 2012.
Busilacchio, M., Di Carlo, P., Aruffo, E., Biancofiore, F., Dari Salisburgo, C., Giammaria, F., Bauguitte, S., Lee, J., Moller, S., Hopkins, J., Punjabi, S., Andrews, S., Lewis, A. C., Parrington, M., Palmer, P. I., Hyer, E., and Wolfe, G. M.: Production of peroxy nitrates in boreal biomass burning plumes over Canada during the BORTAS campaign, Atmos. Chem. Phys., 16, 3485-3497, doi:10.5194/acp-16-3485-2016, 2016.

Coates, J. and Butler, T. M.: A comparison of chemical mechanisms using tagged ozone production potential (TOPP) analysis, Atmos. Chem. Phys., 15, 8795-8808, doi:10.5194/acp-15-87952015, 2015.

Crounse, J. D., Paulot, F., Kjaergaard, H. G., and Wennberg, P. O.: Peroxy radical isomerization in the oxidation of isoprene, Phys. Chem. Chem. Phys., 13, 13607-13613, 2011.

Damian, V., Sandu, A., Damian, M., Potra, F., and Carmichael, G. R.: The kinetic preprocessor KPP - a software environment for solving chemical kinetics, Comput. Chem. Eng., 26, 1567-1579, doi:10.1016/s0098-1354(02)00128-x, 2002.

Dillon, M. B., Lamanna, M. S., Schade, G. W., Goldstein, A., and Cohen, R. C.: Chemical evolution of the Sacramento urban plume: Transport and oxidation, J. Geophys. Res., 107, 4045, doi:10.1029/2001jd000969, 2002.

Edwards, P. M., Evans, M. J., Furneaux, K. L., Hopkins, J., Ingham, T., Jones, C., Lee, J. D., Lewis, A. C., Moller, S. J., Stone, D., Whalley, L. K., and Heard, D. E.: OH reactivity in a South East Asian tropical rainforest during the Oxidant and Particle Photochemical Processes (OP3) project, Atmos. Chem. Phys., 13, 9497-9514, doi:10.5194/acp-13-9497-2013, 2013.

Emmerson, K. M. and Evans, M. J.: Comparison of tropospheric gas-phase chemistry schemes for use within global models, Atmos. Chem. Phys., 9, 1831-1845, doi:10.5194/acp-9-1831-2009, 2009.

Fisher, J. A., Jacob, D. J., Travis, K. R., Kim, P. S., Marais, E. A., Chan Miller, C., Yu, K., Zhu, L., Yantosca, R. M., Sulprizio, M. P., Mao, J., Wennberg, P. O., Crounse, J. D., Teng, A. P., Nguyen, T. B., St. Clair, J. M., Cohen, R. C., Romer, P., Nault, B. A., Wooldridge, P. J., Jimenez, J. L., CampuzanoJost, P., Day, D. A., Hu, W., Shepson, P. B., Xiong, F., Blake, D. R., Goldstein, A. H., Misztal, P. K., Hanisco, T. F., Wolfe, G. M., Ryerson, T. B., Wisthaler, A., and Mikoviny, T.: Organic nitrate chemistry and its implications for nitrogen budgets in an isoprene- and monoterpene-rich atmosphere: constraints from aircraft $\left(\mathrm{SEAC}_{4} \mathrm{RS}\right)$ and ground-based (SOAS) observations in the Southeast US, Atmos. Chem. Phys., 16, 5969-5991, doi:10.5194/acp-16-5969-2016, 2016.

Fuchs, H., Hofzumahaus, A., Rohrer, F., Bohn, B., Brauers, T., Dorn, H., Haseler, R., Holland, F., Kaminski, M., Li, X., Lu, K., Nehr, S., Tillmann, R., Wegener, R., and Wahner, A.: Experimental evidence for efficient hydroxyl radical regeneration in isoprene oxidation, Nat. Geosci., 6, 1023-1026, doi:10.1038/NGEO1964, 2013.

Goliff, W. S., Stockwell, W. R., and Lawson, C. V.: The regional atmospheric chemistry mechanism, version 2, Atmos. Environ., 68, 174-185, doi:10.1016/j.atmosenv.2012.11.038, 2013.

Hildebrandt Ruiz, L. and Yarwood, G.: Interactions between Organic Aerosol and $\mathrm{NO}_{y}$ : Influence on Oxidant Production, Final report for AQRP project 12-012, Austin, TX, 2013. 
Jenkin, M. E., Saunders, S. M., and Pilling, M. J.: The tropospheric degradation of volatile organic compounds: A protocol for mechanism development, Atmos. Environ., 31, 81-104, 1997.

Jenkin, M. E., Young, J. C., and Rickard, A. R.: The MCM v3.3.1 degradation scheme for isoprene, Atmos. Chem. Phys., 15, 11433-11459, doi:10.5194/acp-15-11433-2015, 2015.

Kaiser, J., Li, X., Tillmann, R., Acir, I., Holland, F., Rohrer, F., Wegener, R., and Keutsch, F. N.: Intercomparison of Hantzsch and fiber-laser-induced-fluorescence formaldehyde measurements, Atmos. Meas. Tech., 7, 1571-1580, doi:10.5194/amt-7-15712014, 2014.

Kaiser, J., Wolfe, G. M., Min, K. E., Brown, S. S., Miller, C. C., Jacob, D. J., deGouw, J. A., Graus, M., Hanisco, T. F., Holloway, J., Peischl, J., Pollack, I. B., Ryerson, T. B., Warneke, C., Washenfelder, R. A., and Keutsch, F. N.: Reassessing the ratio of glyoxal to formaldehyde as an indicator of hydrocarbon precursor speciation, Atmos. Chem. Phys., 15, 7571-7583, doi:10.5194/acp-157571-2015, 2015.

Kaiser, J., Skog, K. M., Baumann, K., Bertman, S. B., Brown, S. B., Brune, W. H., Crounse, J. D., de Gouw, J. A., Edgerton, E. S., Feiner, P. A., Goldstein, A. H., Koss, A., Misztal, P. K., Nguyen, T. B., Olson, K. F., St. Clair, J. M., Teng, A. P., Toma, S., Wennberg, P. O., Wild, R. J., Zhang, L., and Keutsch, F. N.: Speciation of $\mathrm{OH}$ reactivity above the canopy of an isoprene-dominated forest, Atmos. Chem. Phys., 16, 93499359, doi:10.5194/acp-16-9349-2016, 2016.

Kim, P. S., Jacob, D. J., Fisher, J. A., Travis, K., Yu, K., Zhu, L., Yantosca, R. M., Sulprizio, M. P., Jimenez, J. L., CampuzanoJost, P., Froyd, K. D., Liao, J., Hair, J. W., Fenn, M. A., Butler, C. F., Wagner, N. L., Gordon, T. D., Welti, A., Wennberg, P. O., Crounse, J. D., St. Clair, J. M., Teng, A. P., Millet, D. B., Schwarz, J. P., Markovic, M. Z., and Perring, A. E.: Sources, seasonality, and trends of southeast US aerosol: an integrated analysis of surface, aircraft, and satellite observations with the GEOS-Chem chemical transport model, Atmos. Chem. Phys., 15, 10411-10433, doi:10.5194/acp-15-10411-2015, 2015.

Kim, S., Wolfe, G. M., Mauldin, L., Cantrell, C., Guenther, A., Karl, T., Turnipseed, A., Greenberg, J., Hall, S. R., Ullmann, K., Apel, E., Hornbrook, R., Kajii, Y., Nakashima, Y., Keutsch, F. N., DiGangi, J. P., Henry, S. B., Kaser, L., Schnitzhofer, R., Graus, M., Hansel, A., Zheng, W., and Flocke, F. F.: Evaluation of $\mathrm{HO}_{x}$ sources and cycling using measurement-constrained model calculations in a 2-methyl-3-butene-2-ol (MBO) and monoterpene (MT) dominated ecosystem, Atmos. Chem. Phys., 13, 20312044, doi:10.5194/acp-13-2031-2013, 2013.

Kim, S., Kim, S.-Y., Lee, M., Shim, H., Wolfe, G. M., Guenther, A. B., He, A., Hong, Y., and Han, J.: Impact of isoprene and HONO chemistry on ozone and OVOC formation in a semirural South Korean forest, Atmos. Chem. Phys., 15, 4357-4371, doi:10.5194/acp-15-4357-2015, 2015.

Knote, C., Tuccella, P., Curci, G., Emmons, L., Orlando, J. J., Madronich, S., Baro, R., Jimenez-Guerrero, P., Luecken, D., Hogrefe, C., Forkel, R., Werhahn, J., Hirtl, M., Perez, J. L., San Jose, R., Giordano, L., Brunner, D., Yahya, K., and Zhang, Y.: Influence of the choice of gas-phase mechanism on predictions of key gaseous pollutants during the AQMEII phase-2 intercomparison, Atmos. Environ., 115, 553568, doi:10.1016/j.atmosenv.2014.11.066, 2015.
Li, X., Rohrer, F., Hofzumahaus, A., Brauers, T., Haseler, R., Bohn, B., Broch, S., Fuchs, H., Gomm, S., Holland, F., Jager, J., Kaiser, J., Keutsch, F. N., Lohse, I., Lu, K. D., Tillmann, R., Wegener, R., Wolfe, G. M., Mentel, T. F., Kiendler-Scharr, A., and Wahner, A.: Missing Gas-Phase Source of HONO Inferred from Zeppelin Measurements in the Troposphere, Science, 344, 292-296, doi:10.1126/science.1248999, 2014.

Mao, J., Paulot, F., Jacob, D. J., Cohen, R. C., Crounse, J. D., Wennberg, P. O., Keller, C. A., Hudman, R. C., Barkley, M. P., and Horowitz, L. W.: Ozone and organic nitrates over the eastern United States: Sensitivity to isoprene chemistry, J. Geophys. Res., 118, 11256-11268, doi:10.1002/jgrd.50817, 2013.

Marais, E. A., Jacob, D. J., Jimenez, J. L., Campuzano-Jost, P., Day, D. A., Hu, W., Krechmer, J., Zhu, L., Kim, P. S., Miller, C. C., Fisher, J. A., Travis, K., Yu, K., Hanisco, T. F., Wolfe, G. M., Arkinson, H. L., Pye, H. O. T., Froyd, K. D., Liao, J., and McNeill, V. F.: Aqueous-phase mechanism for secondary organic aerosol formation from isoprene: application to the southeast United States and co-benefit of $\mathrm{SO}_{2}$ emission controls, Atmos. Chem. Phys., 16, 1603-1618, doi:10.5194/acp-16-16032016, 2016.

Marvin, M., Wolfe, G. M., and Salawitch, R., et al.: Evaluating mechanisms for isoprene oxidation using a constrained chemical box model and SENEX observations of formaldehyde, in preparation, 2016.

Müller, M., Anderson, B. E., Beyersdorf, A. J., Crawford, J. H., Diskin, G. S., Eichler, P., Fried, A., Keutsch, F. N., Mikoviny, T., Thornhill, K. L., Walega, J. G., Weinheimer, A. J., Yang, M., Yokelson, R. J., and Wisthaler, A.: In situ measurements and modeling of reactive trace gases in a small biomass burning plume, Atmos. Chem. Phys., 16, 3813-3824, doi:10.5194/acp16-3813-2016, 2016.

Olson, J. R., Crawford, J. H., Chen, G., Brune, W. H., Faloona, I. C., Tan, D., Harder, H., and Martinez, M.: A reevaluation of airborne $\mathrm{HO}_{x}$ observations from NASA field campaigns, J. Geophys. Res.-Atmos., 111, D10301, doi:10.1029/2005jd006617, 2006.

Paulot, F., Crounse, J. D., Kjaergaard, H. G., Kroll, J. H., Seinfeld, J. H., and Wennberg, P. O.: Isoprene photooxidation: new insights into the production of acids and organic nitrates, Atmos. Chem. Phys., 9, 1479-1501, doi:10.5194/acp-9-1479-2009, 2009a.

Paulot, F., Crounse, J. D., Kjaergaard, H. G., Kurten, A., St Clair, J. M., Seinfeld, J. H., and Wennberg, P. O.: Unexpected Epoxide Formation in the Gas-Phase Photooxidation of Isoprene, Science, 325, 730-733, doi:10.1126/science.1172910, 2009b.

Riedel, T. P., Wolfe, G. M., Danas, K. T., Gilman, J. B., Kuster, W. C., Bon, D. M., Vlasenko, A., Li, S.-M., Williams, E. J., Lerner, B. M., Veres, P. R., Roberts, J. M., Holloway, J. S., Lefer, B., Brown, S. S., and Thornton, J. A.: An MCM modeling study of nitryl chloride $\left(\mathrm{ClNO}_{2}\right)$ impacts on oxidation, ozone production and nitrogen oxide partitioning in polluted continental outflow, Atmos. Chem. Phys., 14, 3789-3800, doi:10.5194/acp-14-37892014, 2014.

Sander, R., Kerkweg, A., Jöckel, P., and Lelieveld, J.: Technical note: The new comprehensive atmospheric chemistry module MECCA, Atmos. Chem. Phys., 5, 445-450, doi:10.5194/acp-5445-2005, 2005.

Sander, R., Baumgaertner, A., Gromov, S., Harder, H., Jöckel, P., Kerkweg, A., Kubistin, D., Regelin, E., Riede, H., Sandu, A., Taraborrelli, D., Tost, H., and Xie, Z.-Q.: The atmospheric chem- 
istry box model CAABA/MECCA-3.0, Geosci. Model Dev., 4, 373-380, doi:10.5194/gmd-4-373-2011, 2011.

Sander, S. P., Abbatt, J., Barker, J. R., Burkholder, J. B., Friedl, R. R., Golden, D. M., Huie, R. E., Kolb, C. E., Kurylo, M. J., Moortgat, G. K., Orkin, V. L., and Wine, P. H.: Chemical Kinetics and Photochemical Data for Use in Atmospheric Studies, Evaluation No. 17, JPL Publication 10-6, Jet Propulsion Laboratory, Pasadena, http://jpldataeval.jpl.nasa.gov (last access: 1 July 2016), 2011.

Saunders, S. M., Jenkin, M. E., Derwent, R. G., and Pilling, M. J.: Protocol for the development of the Master Chemical Mechanism, MCM v3 (Part A): tropospheric degradation of nonaromatic volatile organic compounds, Atmos. Chem. Phys., 3, 161-180, doi:10.5194/acp-3-161-2003, 2003.

Stone, D., Evans, M. J., Edwards, P. M., Commane, R., Ingham, T., Rickard, A. R., Brookes, D. M., Hopkins, J., Leigh, R. J., Lewis, A. C., Monks, P. S., Oram, D., Reeves, C. E., Stewart, D., and Heard, D. E.: Isoprene oxidation mechanisms: measurements and modelling of $\mathrm{OH}$ and $\mathrm{HO}_{2}$ over a South-East Asian tropical rainforest during the OP3 field campaign, Atmos. Chem. Phys., 11, 6749-6771, doi:10.5194/acp-11-6749-2011, 2011.

Su, L., Patton, E. G., Vilà-Guerau de Arellano, J., Guenther, A. B., Kaser, L., Yuan, B., Xiong, F., Shepson, P. B., Zhang, L., Miller, D. O., Brune, W. H., Baumann, K., Edgerton, E., Weinheimer, A., Misztal, P. K., Park, J.-H., Goldstein, A. H., Skog, K. M., Keutsch, F. N., and Mak, J. E.: Understanding isoprene photooxidation using observations and modeling over a subtropical forest in the southeastern US, Atmos. Chem. Phys., 16, 7725-7741, doi:10.5194/acp-16-7725-2016, 2016.

Travis, K. R., Jacob, D. J., Fisher, J. A., Kim, P. S., Marais, E. A., Zhu, L., Yu, K., Miller, C. C., Yantosca, R. M., Sulprizio, M. P., Thompson, A. M., Wennberg, P. O., Crounse, J. D., St. Clair, J. M., Cohen, R. C., Laugher, J. L., Dibb, J. E., Hall, S. R., Ullmann, K., Wolfe, G. M., Pollack, I. B., Peischl, J., Neuman, J. A., and Zhou, $\mathrm{X} .: \mathrm{NO}_{x}$ emissions, isoprene oxidation pathways, vertical mixing, and implications for surface ozone in the Southeast United States, Atmos. Chem. Phys. Discuss., doi:10.5194/acp2016-110, in review, 2016.

Warneke, C., Trainer, M., de Gouw, J. A., Parrish, D. D., Fahey, D. W., Ravishankara, A. R., Middlebrook, A. M., Brock, C. A., Roberts, J. M., Brown, S. S., Neuman, J. A., Lerner, B. M., Lack, D., Law, D., Hübler, G., Pollack, I., Sjostedt, S., Ryerson, T. B., Gilman, J. B., Liao, J., Holloway, J., Peischl, J., Nowak, J. B., Aikin, K. C., Min, K.-E., Washenfelder, R. A., Graus, M. G., Richardson, M., Markovic, M. Z., Wagner, N. L., Welti, A., Veres, P. R., Edwards, P., Schwarz, J. P., Gordon, T., Dube, W. P., McKeen, S. A., Brioude, J., Ahmadov, R., Bougiatioti, A., Lin, J. J., Nenes, A., Wolfe, G. M., Hanisco, T. F., Lee, B. H., LopezHilfiker, F. D., Thornton, J. A., Keutsch, F. N., Kaiser, J., Mao, J., and Hatch, C. D.: Instrumentation and measurement strategy for the NOAA SENEX aircraft campaign as part of the Southeast Atmosphere Study 2013, Atmos. Meas. Tech., 9, 3063-3093, doi:10.5194/amt-9-3063-2016, 2016.

Weininger, D.: SMILES, a chemical language and information system. 1. Introduction to methodology and encoding rules, J. Chem. Inf. Comp. Sci., 28, 31-36, doi:10.1021/ci00057a005, 1988.
Wolfe, G. M. and Thornton, J. A.: The Chemistry of AtmosphereForest Exchange (CAFE) Model - Part 1: Model Description and Characterization, Atmos. Chem. Phys., 11, 77-101, doi:10.5194/acp-11-77-2011, 2011.

Wolfe, G. M., Thornton, J. A., Bouvier-Brown, N. C., Goldstein, A. H., Park, J. H., McKay, M., Matross, D. M., Mao, J., Brune, W. H., LaFranchi, B. W., Browne, E. C., Min, K. E., Wooldridge, P. J., Cohen, R. C., Crounse, J. D., Faloona, I. C., Gilman, J. B., Kuster, W. C., de Gouw, J. A., Huisman, A., and Keutsch, F. N.: The Chemistry of Atmosphere-Forest Exchange (CAFE) Model - Part 2: Application to BEARPEX-2007 observations, Atmos. Chem. Phys., 11, 1269-1294, doi:10.5194/acp-11-12692011, 2011a.

Wolfe, G. M., Thornton, J. A., McKay, M., and Goldstein, A. H.: Forest-atmosphere exchange of ozone: sensitivity to very reactive biogenic VOC emissions and implications for incanopy photochemistry, Atmos. Chem. Phys., 11, 7875-7891, doi:10.5194/acp-11-7875-2011, 2011 b.

Wolfe, G. M., Crounse, J. D., Parrish, J. D., St. Clair, J. M., Beaver, M. R., Paulot, F., Yoon, T. P., Wennberg, P. O., and Keutsch, F. N.: Photolysis, $\mathrm{OH}$ reactivity and ozone reactivity of a proxy for isoprene-derived hydroperoxyenals (HPALDs), Phys. Chem. Chem. Phys., 14, 7276-7286, doi:10.1039/c2cp40388a, 2012.

Wolfe, G. M., Cantrell, C., Kim, S., Mauldin III, R. L., Karl, T., Harley, P., Turnipseed, A., Zheng, W., Flocke, F., Apel, E. C., Hornbrook, R. S., Hall, S. R., Ullmann, K., Henry, S. B., DiGangi, J. P., Boyle, E. S., Kaser, L., Schnitzhofer, R., Hansel, A., Graus, M., Nakashima, Y., Kajii, Y., Guenther, A., and Keutsch, F. N.: Missing peroxy radical sources within a summertime ponderosa pine forest, Atmos. Chem. Phys., 14, 4715-4732, doi:10.5194/acp-14-4715-2014, 2014.

Wolfe, G. M., Hanisco, T. F., Arkinson, H. L., Bui, T. P., Crounse, J. D., Dean-Day, J., Goldstein, A., Guenther, A., Hall, S. R., Huey, G., Jacob, D. J., Karl, T., Kim, P. S., Liu, X., Marvin, M. R., Mikoviny, T., Misztal, P. K., Nguyen, T. B., Peischl, J., Pollack, I., Ryerson, T., St Clair, J. M., Teng, A., Travis, K. R., Ullmann, K., Wennberg, P. O., and Wisthaler, A.: Quantifying sources and sinks of reactive gases in the lower atmosphere using airborne flux observations, Geophys. Res. Lett., 42, 8231-8240, doi:10.1002/2015GL065839, 2015.

Wolfe, G. M., Kaiser, J., Hanisco, T. F., Keutsch, F. N., de Gouw, J. A., Gilman, J. B., Graus, M., Hatch, C. D., Holloway, J., Horowitz, L. W., Lee, B. H., Lerner, B. M., Lopez-Hilifiker, F., Mao, J., Marvin, M. R., Peischl, J., Pollack, I. B., Roberts, J. M., Ryerson, T. B., Thornton, J. A., Veres, P. R., and Warneke, C.: Formaldehyde production from isoprene oxidation across $\mathrm{NO}_{x}$ regimes, Atmos. Chem. Phys., 16, 2597-2610, doi:10.5194/acp16-2597-2016, 2016.

Yarwood, G. S., Rao, M., Yocke, M., and Whitten, G. Z.: Updates to the Carbon Bond Chemical Mechanism: CB05, ENVIRON International Corp., 2005. 